\title{
TRANSAKSI PERBANKAN MELALUI INTERNET BANKING
}

\author{
Asuan \\ Fakultas Hukum Universitas Palembang \\ E-mail:asuan.okay@gmail.com
}

\begin{abstract}
Internet banking is one of the bank's services to customers to obtain information, communicate and conduct banking transactions through the internet network, the implementation of which customers already have a bank account, ATM and User ID and PIN to conduct banking transactions through internet banking based on article 1320 and 1338 Civil Code. Act Number 10 of 1998 concerning Banking in article 5 concerning types of banks, namely commercial banks and people's credit banks and article 40 regarding bank secrecy, including matters of banking transactions through internet banking and legal protection provided by banks regarding the confidentiality of customer data. Disputes on banking transactions through internet banking (banks and debtors) can be resolved by referring to agreements agreed upon by the parties, dispute resolution can be done through court (litigation) or outside the court (non-litigation) based on Law Number 30 of 1999 concerning Arbitration and Alternative Dispute Resolution in article 6 concerning general disputes that can be resolved through arbitration.
\end{abstract}

Keywords: Banking Transactions; Internet Banking

\begin{abstract}
Abstrak
Internet banking merupakan salah satu pelayanan jasa bank terhadap nasabah untuk memperoleh informasi, melakukan komunikasi dan melakukan transaksi perbankan melalui jaringan internet, pelaksanaannya nasabah sudah memiliki rekening bank, ATM dan User ID dan PIN untuk melakukan transaksi perbankan melalui internet banking yang berdasarkan pada pasal 1320 dan 1338 KUH Perdata. Undang-Undang Nomor 10 Tahun 1998 tentang Perbankan pada pasal 5 tentang jenis bank yaitu bank umum dan bank perkreditan rakyat dan pasal 40 tentang kerahasiaan bank termasuk masalah transaksi perbankan melalui internet banking serta perlindungan hukum yang diberikan oleh bank tentang kerahasiaan data nasabah. Sengketa pada transaksi perbankan melalui internet banking (pihak bank dan debitur) dapat diselesaikan dengan mengacu pada perjanjian yang telah disepakati para pihak, penyelesaian sengketa dapat dilakukan melalui pengadilan (litigasi) ataupun di luar pengadilan (nonlitigasi) berdasarkan Undang-Undang Nomor 30 Tahun 1999 tentang Arbitrase dan Alternatif Penyelesaian Sengketa dalam pasal 6 tentang sengketa umum yang dapat diselesaikan melalui arbitrase.

Kata Kunci: Transaksi Perbankan; Internet Banking
\end{abstract}

\section{PENDAHULUAN}

Negara Republik Indonesia merupakan negara berkembang yang telah menyadari ketertinggalannya di bidang pembangunan. Untuk mengejar ketertinggalannya tersebut dan sebagai upaya untuk meningkatkan taraf hidup masyarakat sejalan dengan perkembangan jaman yang mengarah pada modernisasi, maka dilakukan usaha yang disebut pembangunan nasional. Pembangunan nasional merupakan upaya 
Asuan, Transaksi Perbankan Melalui Internet Banking, Halaman 317-335

pembangunan yang berkesinambungan yang dilakukan secara menyeluruh terhadap segala sektor perikehidupan yang meliputi kehidupan masyarakat, bangsa dan negara, untuk mewujudkan tujuan nasional sebagaimana tercantum dalam alinea IV Pembukaan Undang-Undang Dasar 1945 yaitu melindungi segenap bangsa dan seluruh tumpah darah Indonesia, memajukan kesejahteraan umum, mencerdaskan kehidupan bangsa serta ikut melaksanakan ketertiban dunia berdasarkan kemerdekaan, perdamaian abadi dan keadilan sosial. Pembangunan nasional bangsa Indonesia dimaksudkan sebagai upaya untuk membangun manusia Indonesia seutuhnya dan masyarakat Indonesia seluruhnya demi terwujudnya suatu masyarakat yang sejahtera, adil, makmur dan merata baik materiil maupun spiritual. $^{1}$

$$
\text { Pembangunan nasional yang }
$$
merupakan proses modernisasi telah membawa dampak positif dan negatif bagi kehidupan manusia. Perkembangan jaman yang semakin pesat sebagai akibat dari pembangunan banyak memberikan pengaruh dalam kemajuan budaya dan

${ }^{1}$ Sri Soemantri M, Bunga Rampai Hukum Tata Negara Indonesia, Bandung: Penerbit Alumni, Cetakan Edisi ke XV, 2007, hlm. 21. ilmu pengetahuan dan teknologi yang menimbulkan permasalahan yang multikompleks, sehingga dalam rangka mewujudkan pembangunan yang berkesinambungan untuk terwujudnya masyarakat yang adil dan makmur berdasarkan Pancasila dan UUD 1945 diperlukan suatu peran serta baik dari sektor pemerintah maupun swasta yang senantiasa memperhatikan keserasian, keselarasan, dan kesinambungan berbagai unsur pembangunan di bidang ekonomi dan pembangunan.

Salah satu sarana untuk mewujudkan pembangunan tersebut adalah adanya peran serta dari lembaga keuangan yang mengatur tatanan sistem ekonomi yang menunjang pelaksanaan tujuan pembangunan nasional. Lembaga keuangan pada dasarnya mempunyai peran yang sangat strategis dalam mengembangkan perekonomian suatu bangsa. Tumbuhnya perkembangan lembaga keuangan secara baik dan sehat akan mampu mendorong perkembangan ekonomi bangsa. Lembaga keuangan tersebut dapat berbentuk Lembaga Keuangan Bank dan Lembaga Keuangan Bukan Bank. Bank adalah lembaga keuangan yang menjadi tempat bagi perseorangan, badan usaha baik milik swasta maupun milik negara, 
Asuan, Transaksi Perbankan Melalui Internet Banking, Halaman 317-335

dan lembaga pemerintah untuk meningkatkan efisien dan mutu menyimpan dananya yang bertujuan untuk memberikan kredit dan jasa-jasa. pelayanannya kepada masyarakat dengan Melalui kegiatan perkreditan dan berbagai jasa yang diberikan, bank melayani kebutuhan pembiayaan serta melancarkan mekanisme sistem pembayaran bagi semua sektor perekonomian. $^{2}$

Peran yang strategis tersebut terutama disebabkan oleh fungsi utama bank sebagai suatu wadah yang dapat menghimpun dan menyalurkan dana masyarakat secara efektif dan efisien, yang menunjang pelaksanaan pembangunan nasional dalam rangka meningkatkan pemerataan pembangunan dan hasil-hasilnya, pertumbuhan ekonomi dan stabilitas nasional ke arah peningkatan taraf hidup rakyat banyak. Di Indonesia masalah yang terkait dengan bank diatur dalam Undang-Undang Nomor 10 Tahun 1998 tentang Perubahan Undang-Undang Nomor 7 Tahun 1992 tentang Perbankan.

Di dalam industri keuangan yang semakin canggih dewasa ini, kebutuhan akan jasa perbankan dan persaingan antar bank semakin meningkat, sehingga perbankan diharuskan untuk senantiasa

${ }^{2}$ Sutan Remi Sjahdeini, Hukum Siber Sistem Pengamanan E-Commerce, Bandung: PT Citra Aditya Bakti, 2001, hlm. 309. cara menyesuaikan diri agar mampu menampung tuntutan pengembangan jasa perbankan. Lembaga keuangan bank memberikan layanannya tidak hanya melalui bentuk-bentuk konvensional, tetapi sudah mulai beralih pada pemanfaatan teknologi informasi. Hal ini dipacu oleh perkembangan ilmu pengetahuan dan teknologi informasi yang mampu mendukung sistem transaksi perbankan. Kerangka kerja lembaga keuangan bank harus terus berevolusi mengikuti perkembangan teknologi terkini, selain itu bank juga harus terus berinovasi sejalan dengan perkembangan teknologi itu sendiri. Bank-bank masa kini semakin mendorong peningkatan kualitas dan keterjangkauan yang lebih luas bagi nasabahnya dalam memperoleh layanan perbankan, sasarannya adalah bagaimana menjangkau dan memudahkan nasabah untuk menikmati berbagai fasilitas layanan perbankan tanpa harus terintangi ruang dan waktu.

Semakin pesatnya perkembangan teknologi infomasi pada masa sekarang ini menjadikan internet banking sebagai alternatif yang banyak dipakai oleh bank 
Asuan, Transaksi Perbankan Melalui Internet Banking, Halaman 317-335

saat ini. Internet banking merupakan dimulai dari penawaran jasa pelayanan jasa perbankan untuk perbankan melalui situs-situs yang mempermudah nasabah di dalam dibuat oleh bank yang melakukan transaksi perbankan, karena bersangkutan sampai pada tawaran untuk internet banking memanfaatkan teknologi melakukan transaksi secara online sistem informasi sesuai dengan melalui media internet. Di dalam layanan Surat Keputusan Direksi Bank Indonesia Nomor

27/164/KEP/DIR/1995 tentang

Penggunaan Teknologi Sistem Informasi oleh Bank dan

Surat

Keputusan

Direksi

Bank

Indonesia Nomor 31/175/KEP/DIR/1998 tentang Penyempurnaan Teknologi Sistem Informasi Bank dalam Menghadapi Tahun 2000. Layanan internet banking merupakan wujud dari responsifnya lembaga keuangan bank terhadap peluang dalam persaingan saat ini. Bagi sektor perbankan, penggunaan internet banking sangat berpotensi mengefisiensi biaya sekaligus meningkatkan pendapatan melalui sistem yang jauh lebih efektif daripada bentuk konvensional. Layanan internet banking menawarkan berbagai macam kemudahan dalam kegiatan transaksi perbankan di Indonesia. $^{3}$

Kemudahan itu antara lain

${ }^{3}$ Budi Agus Riswandi, Aspek Hukum Internet Banking, Jakarta: Raja Grafindo Persada, 2005, hlm. 29-30. internet banking kita bisa melakukan aktivitas perbankan hanya melalui komputer yang terhubung dengan internet. $^{4}$

Penggunaan layanan internet banking sangat praktis dan sangat berguna bagi masyarakat yang malas berantri-antri di bank atau melalui prosedur bank yang bertele-tele dan berbelit-belit, karena hanya tinggal klik, kita sudah bisa melakukan transaksi perbankan. Untuk menjadi nasabah layanan internet banking, terlebih dahulu nasabah harus mendaftar. Di dalam melakukan pendaftaran itu otomatis bank dan nasabah terikat dalam suatu perjanjian. Dari sini dapat dilihat bahwa transaksi perbankan melalui internet banking terkait dengan Hukum Perjanjian, oleh karena itu perlu diketahui juga secara mendalam mengenai Hukum Perjanjian. Dilihat dari suatu sisi, kemunculan teknologi internet banking ini telah memberikan kemudahan

\footnotetext{
${ }^{4}$ Mariam Darus Badrulzaman, Kontrak Dagang Elektronik Tinjauan dari Aspek Hukum Perdata, Bandung: Penerbit PT. Citra Aditya Bakti, 2001, hlm. 271.
} 
Asuan, Transaksi Perbankan Melalui Internet Banking, Halaman 317-335

dalam melakukan transaksi perbankan, meningkatkan efisiensi biaya sekaligus memberikan keuntungan yang tinggi terhadap sektor perbankan, tetapi di sisi lain transaksi perbankan melalui internet banking dapat saja menimbulkan sengketa di kemudian hari. Dari berbagai keuntungan yang diberikan, penggunaan layanan internet banking juga tidak luput dari risiko munculnya permasalahan hukum dalam transaksi perbankan yang dilakukan, oleh karena itu dalam menyelesaikan permasalahan yang terjadi perlu adanya upaya penyelesaian sengketa. $^{5}$

Penyelesaian sengketa antara pihak bank dengan nasabah dapat diselesaikan dengan mengacu pada perjanjian yang telah disepakati oleh para pihak, apakah penyelesaian sengketa dilakukan melalui pengadilan (litigasi) atau di luar pengadilan (nonlitigasi). Transaksi perbankan melalui internet banking harus kita lihat lebih mendalam lagi, karena kita harus mengetahui apakah itu internet banking dan apakah pengaturan dari transaksi perbankan melalui internet banking tersebut di Indonesia dapat menjamin kepastian hukum dan keadilan bagi para pihak yang terkait, serta

5 Resa Raditio, Aspek Hukum Transaksi Elektronik; Perikatan, Pembuktian Dan PenyelesaianSengketa, Yogyakarta: Graha Ilmu, 2014. hlm. 25. bagaimana upaya penyelesaian sengketa jika terjadi permasalahan hukum dalam transaksi perbankan melalui internet banking.

\section{PEMBAHASAN}

\section{A. Pelaksanaan}

Transaksi Perbankan Melalui Internet Baking Menurut

\section{Undang-Undang Perbankan}

Perkembangan layanan perbankan dewasa ini mengalami kemajuan yang pesat sekali. Ini dibuktikan dengan adanya layanan perbankan lewat sarana internet atau yang lebih dikenal dengan internet banking. Dengan adanya keuntungan dan kemudahan yang ditawarkan oleh layanan internet banking ini maka dunia perbankan saling berlomba untuk menawarkan berbagai macam layanan bagi nasabah dalam melakukan transaksi perbankan.

Definisi internet banking menurut Surat Edaran Bank Indonesia Nomor 6/18/DPNP Tanggal 20 April 2004 tentang Penerapan Manajemen Risiko pada Aktivitas Pelayanan Jasa Bank melalui Internet Banking yakni bahwa internet banking merupakan salah satu pelayanan jasa bank yang memungkinkan nasabah untuk memperoleh informasi, melakukan komunikasi dan melakukan 
Asuan, Transaksi Perbankan Melalui Internet Banking, Halaman 317-335

transaksi perbankan melalui jaringan internet.

Di Indonesia saat ini terdapat beberapa bank yang telah menyelenggarakan layanan internet banking untuk mempermudah transaksi perbankan yang dilakukan oleh bank dan nasabah, di antaranya yakni Bank Rakyat Indonesia, Bank Mandiri, Bank Central Asia (BCA), HSBC, Citibank, Bank Negara Indonesia (BNI), Bank Internasional Indonesia (BII), Bank Permata, dan Bank Lippo. ${ }^{6}$

Internet banking merupakan bagian dari electronic banking yang merupakan inovasi dari jenis rekening tabungan dan atau rekening giro rupiah. Sebagai sistem layanan yang bersumber pokok pada kedua rekening tersebut, maka salah satu syarat bagi nasabah yang menginginkan layanan internet banking ini terlebih dahulu harus mempunyai rekening tabungan dan atau rekening giro serta harus mempunyai alamat $e$-mail dan hardware/software dengan kualifikasi tertentu. Meskipun demikian, nasabah yang telah memiliki jenis rekening tabungan dan atau rekening giro serta alamat e-mail tidak secara otomatis dapat diberikan layanan internet banking ini,

6 http://www.bankmandiri.com, diakses Tanggal 10-12 Juli 2019. nasabah harus melakukan pendaftaran atau registrasi terlebih dahulu untuk menjadi nasabah internet banking, kecuali jika secara tegas dinyatakan dalam syarat dan ketentuan produk rekening tabungan dan atau rekening giro yang dinyatakan bahwa fasilitas kedua rekening tersebut secara otomatis melekat layanan internet banking.

Pendaftaran atau registrasi dapat dilakukan melalui kantor cabang pada bank yang bersangkutan, dengan memenuhi dan menyetujui syarat dan ketentuan yang merupakan perjanjian baku yang telah ditetapkan oleh pihak bank untuk disetujui oleh nasabah yang ingin menjadi nasabah internet banking. Syarat dan ketentuan ini biasanya terdapat pada screen ATM bank yang bersangkutan, situs internet bank yang bersangkutan, atau dalam bentuk formulir yang dapat diperoleh dari kantor cabang bank yang bersangkutan. Setelah terdaftar menjadi nasabah internet banking, nasabah akan memperoleh User ID (identitas pengguna) dan PIN (nomor identitas pribadi) yang merupakan kode rahasia dan kewenangan pengguna yang hanya diketahui oleh nasabah yang bersangkutan sebagai verifikasi pada saat nasabah akan melakukan transaksi perbankan melalui 
Asuan, Transaksi Perbankan Melalui Internet Banking, Halaman 317-335

internet banking, yang dimaksudkan untuk menjaga kerahasiaan identitas dan semua informasi keuangan nasabah, sehingga semua transaksi perbankan hanya dapat dilakukan oleh nasabah yang bersangkutan. Mengenai jumlah digit dan atau sistem aktivasi melalui User ID dan PIN serta tata cara pengiriman User ID dan PIN tersebut, masing-masing bank berbeda antara yang satu dengan yang lain. Hal ini terkait dengan sistem teknologi dan pilihan sistem pengamanan yang dimiliki setiap bank yang menyelenggarakan layanan internet banking. Untuk mengamankan transaksi pengguna layanan internet banking, maka terdapat bank yang mewajibkan penggunaan token PIN, yaitu alat pengaman yang berfungsi menghasilkan PIN yang dapat digunakan untuk melakukan transaksi perbankan melalui internet. Dengan token PIN ini, maka PIN nasabah akan selalu berganti-ganti setiap saat, sehingga keamanan transaksi perbankan lebih aman dan terjamin. ${ }^{7}$

Jenis layanan internet banking yang ditawarkan oleh bank dan dapat diakses oleh nasabah antara bank satu dengan yang lain pun berbeda-beda. Sebagai contoh di dalam

${ }^{7}$ Maryanto Supriyono, Buku Pintar Perbankan, Bandung: CV. Andi Ofsfet, 2010, hlm. 70. layanan Internet Banking Mandiri, layanan yang terdapat dalam Internet Banking Mandiri, Internet Banking BRI dan internet banking bank lainnya yaitu :

a. Informasi Saldo

Informasi saldo yang dapat dilakukan adalah saldo tabungan, giro, deposito, dan pinjaman.

b. Informasi Sepuluh Transaksi Terakhir Nasabah dapat mengetahui informasi sepuluh transaksi terakhir untuk rekening tabungan dan giro.

c. Transaksi transfer, Transaksi transfer yang dapat dilakukan oleh nasabah, yaitu :

1. Transfer antar rekening sendiri

2. Transfer ke rekening pihak ketiga yang telah didaftarkan

d. Pembayaran

Pembayaran yang dapat dilakukan oleh nasabah yaitu pembayaran tagihan listrik, telepon selular, pajak, dan tagihan-tagihan lain.

e. Pembelian

Pembelian disini meliputi pembelian voucher pulsa telepon selular.

f. Mengubah PIN, Melakukan perubahan PIN dapat dilakukan sesuai dengan keinginan nasabah. ${ }^{8}$

Fitur dan jenis layanan internet banking selalu berkembang sesuai dengan perkembangan teknologi informasi, di mana setiap saat dapat berubah. Di samping itu, informasi dan transaksi perbankan melalui internet banking hanya bersifat pemberitahuan, sehingga nasabah

\footnotetext{
${ }^{8}$ Tentang pelaksanaan internet baking pada bank mandiri, http://www.bankmandiri.com, diakses Tanggal 12 Juli 2019.
} 
Asuan, Transaksi Perbankan Melalui Internet Banking, Halaman 317-335

sebaiknya tetap meminta data transaksi tersebut ke cabang bank yang bersangkutan menyangkut hal pembuktian. Berkaitan dengan pembuktian, di dalam ketentuan layanan internet banking biasanya terdapat ketentuan mengenai pembuktian, sebagai contoh di dalam Internet Banking Bank terdapat ketentuan sebagai berikut

1. Setiap transaksi finansial dari nasabah yang tersimpan pada pusat data Bank dalam bentuk apapun, termasuk namun tidak terbatas pada catatan, tape/cartridge, print out komputer, komunikasi yang ditransisi secara elektronik antara Bank dan nasabah, merupakan alat bukti yang sah, kecuali nasabah dapat membuktikan sebaliknya.

2. Nasabah menyetujui semua komunikasi dan instruksi dari nasabah yang diterima oleh Bank merupakan alat bukti yang sah meskipun tidak dibuat dokumen tertulis ataupun dikeluarkan dokumen yang ditandatangani.

Internet banking memberikan berbagai manfaat bagi nasabah sebagai pengguna layanan internet banking dan bank sebagai penyelenggara layanan internet banking, manfaat tersebut antara lain : a. Manfaat bagi nasabah yang menggunakan layanan internet banking, yaitu :

1. Dapat melakukan transaksi perbankan kapan saja, dimana saja selama 24 (dua puluh empat) jam sehari dan 7 (tujuh) hari seminggu;

2. Proses transaksi perbankan menjadi lebih cepat;

3. Fitur layanan di dalam layanan internet banking sangat beragam dan lengkap.

b. Manfaat bagi bank menyelenggarakan layanan internet banking, yaitu :

1. Menurunkan biaya transaksi di dalam perbankan;

2. Meningkatkan image bank;

3. Meningkatkan loyalitas nasabah kepada bank;

4. Menghasilkan fee based income.

Penghentian akses layanan internet banking bagi nasabah dapat dilakukan oleh pihak bank apabila:

a. Nasabah meminta kepada bank untuk menghentikan akses layanan internet banking, karena:

1. Nasabah menutup semua rekening yang dapat diakses melalui layanan internet banking;

2. User ID dan atau PIN nasabah pengguna lupa.

b. Nasabah salah memasukkan PIN sebanyak tiga kali atau sesuai ketentuan bank yang 
Asuan, Transaksi Perbankan Melalui Internet Banking, Halaman 317-335

bersangkutan.

c. Diterimanya laporan dari nasabah mengenai dugaan atau diketahuinya User ID dan PIN oleh pihak lain yang tidak berwenang.

b. Bank melaksanakan suatu keharusan sesuai ketentuan perundang- undangan yang berlaku. ${ }^{9}$

Transaksi perbankan melalui internet banking, bagaimanapun termasuk ruang lingkup hukum perdata. Esensi dalam transaksi perbankan tersebut adalah adanya suatu perikatan yang lahir dari suatu perjanjian, sehingga permasalahan hukum utama dalam transaksi perbankan melalui internet banking adalah permasalahan "kontrak", dimana semua transaksi perbankan yang dilakukan oleh nasabah semata-mata berdasarkan hukum perjanjian yang konvensional.

Menurut Pasal 1313 KUH Perdata, perjanjian adalah suatu perbuatan dengan mana satu orang atau lebih mengikatkan dirinya terhadap satu orang atau lebih. Berdasarkan rumusan tersebut ditegaskan bahwa perjanjian mengakibatkan seseorang mengikatkan dirinya pada orang lain, sehingga lahir kewajiban atau prestasi dari satu atau lebih pihak kepada satu atau lebih pihak lain. Perjanjian dibuat dengan pengetahuan dan kehendak bersama dari para pihak, dengan tujuan untuk

9 Rachmadi Usman, Aspek-aspek Hukum Perbankan di Indonesia, Jakarta: Gramedia, 2003, hlm. 35-36. menciptakan atau melahirkan kewajiban pada salah satu pihak atau kedua belah pihak yang membuat perjanjian tersebut. ${ }^{10}$

Pembedaan antara kemampuan objektif dan subyektif terhadap lahirnya suatu perikatan dalam ketententuan umum tentang perikatan yang lahir dari perjanjian yang dirumuskan dalam Pasal 1320 KUH Perdata yang merupakan syarat sahnya perjanjian, dimana disebutkan bahwa:

Supaya terjadi persetujuan yang sah, perlu dipenuhi empat syarat :

1. Sepakat mereka yang mengikatkan dirinya

2. Kecakapan untuk membuat suatu perikatan

3. Suatu pokok persoalan tertentu 4. Suatu sebab yang tidak terlarang. ${ }^{11}$

Mengenai transaksi perbankan melalui internet banking menurut Undang-Undang Nomor 10 Tahun 1998 tentang Perubahan Undang-Undang Nomor 7 Tahun 1992 tentang Perbankan merupakan wujud dari aturan yang menjadi landasan hukum dalam bidang perbankan, yang menjadi hukum positif perbankan di Indonesia. Di Indonesia,

\footnotetext{
${ }^{10}$ Subekti, Hukum Perjanjian, Jakarta: PT Intermasa, Cetakan Edisi Baru, 2002, hlm. 3.

${ }^{11}$ Kartini Muljadi Gunawan Widjaja, Seri Hukum Perikatan (Perikatan Pada Umumnya), Jakarta: PT. Raja Grafindo Persada, 2003, hlm. 26.
} 
Asuan, Transaksi Perbankan Melalui Internet Banking, Halaman 317-335

masalah yang terkait dengan bank diatur dalam undang-undang ini, termasuk hal-hal yang berkaitan dengan transaksi perbankan melalui internet banking.

Di dalam Pasal 1 Undang-Undang Nomor 10 Tahun 1998 tentang Perbankan menyatakan bahwa bank adalah badan usaha yang menghimpun dana dari masyarakat dalam bentuk simpanan dan menyalurkannya kepada masyarakat dalam bentuk kredit dan atau bentuk-bentuk lainnya dalam rangka meningkatkan taraf hidup rakyat banyak. yang berbeda. Pengertian bank lebih diorientasikan pada badan usahanya dan kegiatan bank, sementara pengertian perbankan lebih luas lagi di dalamnya meliputi kelembagaan dan cara serta proses dalam melaksanakan kegiatan usahanya.

Selanjutnya, di dalam Pasal 5 Undang-Undang Perbankan dinyatakan bahwa menurut jenisnya, bank terdiri dari:

1. Bank Umum, yakni bank yang melaksanakan kegiatan usaha secara konvensional dan atau berdasarkan Prinsip Syariah yang dalam kegiatannya memberikan jasa dalam lalu lintas pembayaran.

2. Bank Perkreditan Rakyat, yakni bank yang melaksanakan kegiatan usaha secara konvensional atau berdasarkan prinsip syariah yang dalam kegiatannya tidak memberikan jasa dalam lalu lintas pembayaran.

Berdasarkan lingkup kegiatan usaha bank tersebut, transaksi perbankan yang dapat dilakukan melalui layanan internet banking, antara lain:

1. Transfer dana rupiah atau pemindahbukuan antar rekening bank yang sama serta up date daftar transfer. Di samping itu, terdapat internet banking yang dapat melakukan transfer ke bank lain di dalam negeri, melalui kliring dan transfer terjadwal ;

2. Pembayaran tagihan-tagihan, misalnya tagihan telepon, listrik, air, berbelanja lewat $e$-commerce, dan lain sebagainya ;

3. Pembukaan deposito berjangka, sesuai dengan fitur produk deposito pada bank yang bersangkutan

4. Informasi rekening, misalnya posisi saldo rekening, suku bunga dan kurs valuta ;

5. Pendaftaran layanan notifikasi SMS, yaitu melakukan pendaftaran atau perubahan layanan notifikasi SMS ke ponsel nasabah pengguna ; 
Asuan, Transaksi Perbankan Melalui Internet Banking, Halaman 317-335

6. Permintaan buku cheque/ bilyet giro ;

7. Up date profil, antara lain mengubah PIN atau mengubah alamat $e$ - mail. ${ }^{12}$

Mengenai pembinaan dan pengawasan terhadap kegiatan usaha bank dilakukan oleh Bank Indonesia dengan menetapkan ketentuan yang wajib dipenuhi oleh bank sesuai Pasal 29 Undang-Undang Perbankan sebagai berikut :

1. Bank wajib memelihara tingkat kesehatan bank sesuai dengan ketentuan kecukupan modal, kualitas aset, kualitas manajemen, likuiditas, rentabilitas, solvabilitas, dan aspek lain yang berhubungan dengan usaha bank, dan wajib melakukan kegiatan usaha sesuai dengan prinsip kehati-hatian.

2. Di dalam memberikan kredit atau pembiayaan berdasarkan Prinsip Syariah dan melakukan kegiatan usaha lainnya, bank wajib menempuh cara-cara yang tidak merugikan bank dan kepentingan nasabah yang mempercayakan dananya kepada bank.

3. Untuk kepentingan nasabah, bank wajib menyediakan informasi

12 Try Widiyono, Aspek Hukum Operasional Transaksi Produk Perbankan di Indonesia, Bogor: Galia Indonesia, 2006, hlm. 79. mengenai kemungkinan timbulnya risiko kerugian sehubungan dengan transaksi nasabah yang dilakukan melalui bank.

Pembinaan dan pengawasan bank ini perlu dilaksanakan agar bank sebagai penyelenggara layanan internet banking dapat menjamin keamanan transaksi perbankan yang dilakukan oleh nasabah, serta nasabah dapat mengetahui mengenai risiko-risiko yang mungkin timbul dalam transaksi perbankan yang dilakukan dalam layanan internet banking melalui informasi layanan internet banking yang diberikan oleh bank.

Ketentuan yang terdapat dalam Pasal 40 Undang-Undang Perbankan tersebut mencerminkan akan asas atau prinsip kerahasiaan bank, yang sekiranya mampu dipergunakan untuk menetapkan dan memberikan perlindungan hukum atas data pribadi nasabah dalam melakukan transaksi perbankan melalui internet banking, mengingat bank terutama bekerja dengan dana dari masyarakat yang disimpan pada bank atas dasar kepercayaan. Mengenai kerahasiaan bank ini, untuk perkembangan saat ini tidak cukup lagi mengantisipasi 
Asuan, Transaksi Perbankan Melalui Internet Banking, Halaman 317-335

dinamika bisnis sektor perbankan. banking.

Prinsip kerahasiaan bank ini dalam

Oleh karena itu, keberadaan konteks perlindungan hukum atas data self-regulation tidak menjadi suatu pribadi nasabah dapat saja diterapkan, instrumen yang betul-betul dapat namun penerapannya di dalam memberikan perlindungan penuh penyelenggaraan internet banking menjadi tidak optimal, sebab perlindungan hukum atas data pribadi nasabah yang ada pada ketentuan ini terbatas hanya pada data yang disimpan dan dikumpulkan oleh bank, padahal di dalam penyelenggaraan internet banking, data nasabah yang ada tidak hanya data yang disimpan dan dikumpulkan, tetapi termasuk data yang ditransfer oleh pihak nasabah dari sarana komputer yang terhubung dengan internet dimana nasabah melakukan transaksi perbankan. Bank tidak mampu lagi untuk mengantisipasi dampak dari pemanfaatan layanan internet banking. Ketidakmampuan ini disebabkan karena karakteristik layanan internet banking untuk memfasilitasi transaksi perbankan yang berbeda dengan perbankan secara konvensional. Melihat pada kondisi demikian, dapat disimpulkan bahwa Undang- Undang Perbankan belum mampu memberikan perlindungan hukum sepenuhnya atas data pribadi nasabah dalam penyelenggaraan internet terhadap data pribadi nasabah dan bank jika instrumen undang-undang tidak segera dibentuk oleh pemerintah, artinya kebutuhan terhadap undang-undang mengenai perlindungan data pribadi sangat dibutuhkan terutama dalam industri perbankan yang terus berkembang dengan pesat.

\section{B. Penyelesaian Sengketa dalam Transaksi Perbankan Melalui Internet Banking}

Internet banking sebagai inovasi dari produk perbankan yang memanfaatkan teknologi sistem informasi, selain memberikan keuntungan dan kemudahan dalam transaksi perbankan juga mempunyai dampak risiko yang dapat merugikan kepentingan pihak bank maupun nasabah sebagai penyelenggara dan pengguna layanan internet banking dalam transaksi perbankan yang dilakukan. Transaksi perbankan melalui internet banking dapat menimbulkan permasalahan hukum yang dapat merugikan para pihak, 
Asuan, Transaksi Perbankan Melalui Internet Banking, Halaman 317-335

sehingga memungkinkan munculnya sengketa antara para pihak di kemudian hari. Permasalahan hukum yang mungkin muncul dalam transaksi perbankan melalui internet banking salah satunya yakni menyangkut keamanan sistem informasi. Internet banking yang memanfaatkan teknologi sistem informasi membuat transaksi perbankan yang dilakukan semakin berisiko. Dengan kenyataan seperti ini, faktor keamanan merupakan hal yang penting dan paling perlu diperhatikan. ${ }^{13}$

Kecanggihan teknologi tak selamanya menjamin keamanan dalam melakukan transaksi perbankan. Sebagai contoh, pada Tahun 2010, dunia perbankan diributkan oleh kasus pembobolan internet banking milik Bank BCA, yang lebih dikenal dengan kasus klikbca. Kasus ini dilakukan oleh Steven Haryanto yang dengan sengaja membuat situs palsu layanan Internet Banking BCA dengan membeli domain-domain internet dengan nama mirip_www.klikbca.com (situs asli Internet Banking BCA), antara lain wwwklikbca.com, kilkbca.com, clikbca.com, klickbca.com, dan

${ }^{13}$ Gunarto Suhardi. 2003. Usaha Perbankan dalam Perspektif Hukum, Yogyakarta: Kanisius, 2003, hlm. 119. klikbac.com dengan tampilan yang sama persis dengan situs Internet Banking BCA. Dalam hal ini pelaku memanfaatkan kesalahan ketik yang mungkin dilakukan oleh nasabah, sehingga pelaku mampu mendapatkan User ID dan PIN dari nasabah yang memasuki situs plesetan tersebut. Di dalam kasus ini, diperkirakan 130 nasabah tercuri datanya. Berdasarkan contoh kasus di atas, dapat dilihat bahwa di dalam hal ini yang paling dirugikan adalah nasabah pengguna layanan internet banking.

Dari sinilah muncul kemungkinan terjadi sengketa antara para pihak, yakni pihak bank dengan nasabah. Sengketa yang timbul antara pihak bank dengan nasabah dapat diselesaikan dengan mengacu pada perjanjian yang telah disepakati oleh para pihak, mengingat belum ada pengaturan secara khusus tentang transaksi perbankan melalui internet banking dalam sistem perundang-undangan di Indonesia, sehingga belum ada aturan yang tegas mengenai upaya hukum ataupun sanksi hukum yang dapat diterapkan.

Perjanjian merupakan prosedur dan undang-undang bagi pihak-pihak yang membuatnya. Hal ini berarti bahwa pejanjian yang dibuat itu sah dan 
Asuan, Transaksi Perbankan Melalui Internet Banking, Halaman 317-335

mengikat kedua belah pihak, dalam hal ini yaitu pihak bank dengan nasabah. Kedua belah pihak wajib melaksanakan isi perjanjian dan tidak dibenarkan untuk membatalkan atau mengakhiri perjanjian tanpa persetujuan kedua belah pihak ataupun tanpa alasan yang dibenarkan oleh undang-undang. Hal ini sesuai dengan rumusan Pasal 1338 KUH Perdata. Apabila suatu perjanjian telah disepakati, maka masing-masing pihak terikat karenanya dan berkewajiban memenuhi prestasinya. Akan tetapi, di dalam pelaksanaannya terdapat kemungkinan mengalami hambatan-hambatan yang pada akhirnya mempengaruhi tujuan perjanjian yang telah disepakati, seperti halnya munculnya sengketa antara pihak bank dan nasabah akibat permasalahan hukum yang timbul dalam layanan internet banking, yang pada akhirnya mempengaruhi tujuan perjanjian yang telah disepakati para pihak. Di dalam suatu perjanjian memuat syarat-syarat sahnya perjanjian. Suatu hal tertentu merupakan syarat obyektif dari perjanjian, yakni mengenai apa yang diperjanjikan hak-hak dan kewajiban kedua belah pihak jika timbul perselisihan. Di dalam perjanjian yang disepakati para pihak dalam layanan internet banking, sedikitnya juga memuat dalam klausul perjanjian mengenai hak dan kewajiban para pihak apabila terjadi perselisihan, serta upaya hukum apa yang akan digunakan untuk menyelesaikan sengketa antara para pihak. Sengketa yang terjadi antara pihak bank dengan nasabah dapat diselesaikan melalui pengadilan (litigasi) maupun di luar pengadilan (nonlitigasi). ${ }^{14}$

Meskipun demikian, keberadaan peradilan sebagai pelaksana kekuasaan kehakiman tetap dibutuhkan. Tempat dan kedudukan peradilan dalam negara hukum dan masyarakat demokrasi masih dapat diandalkan, antara lain :

1. Peradilan berperan sebagai katup penekan atas segala pelanggaran hukum, ketertiban masyarakat, dan pelanggaran ketertiban umum.

2. Peradilan masih tetap diharapkan berperan sebagai tempat terakhir mencari kebenaran dan keadilan, sehingga peradilan masih tetap diandalkan sebagai badan yang berfungsi menegakkan kebenaran dan keadilan. ${ }^{15}$

${ }^{14}$ Munir Fuady, Arbitrase Nasional, Bandung: PT. Citra Aditya Bakti, 2003, hlm. 37.

${ }^{15}$ Yahya Harahap, Beberapa Tinjuan Mengenai Sistem Peradilan, Bandung: PT. Citra Aditya Bakti, 2005, hlm. 237. 
Asuan, Transaksi Perbankan Melalui Internet Banking, Halaman 317-335

Keputusan dari para pihak, dalam batas tertentu litigasi sekurangkurangnya menjamin bahwa kekuasaan tidak dipengaruhi hasil dan dapat menjamin ketentraman sosial. Sebagai suatu ketentuan umum dalam proses gugatan, litigasi sangat baik untuk menemukan kesalahan-kesalahan dan masalah-masalah posisi pihak lawan. Litigasi juga memberikan suatu standar prosedur yang adil dan memberikan peluang yang luas kepada para pihak untuk didengar keterangannya sebelum diambil keputusan. Litigasi tidak hanya menyelesaikan sengketa, tetapi juga menjamin suatu bentuk ketertiban umum yang tertuang dalam undang-undang, baik secara eksplisit maupun implisit.

\section{Berdasarkan}

peraturan perundang-undangan yang berlaku di Indonesia, penyelesaian sengketa perdata disamping dapat diajukan ke peradilan umum juga terbuka kemungkinan diajukan melalui arbitrase dan Alternatif Penyelesaian Sengketa. Menurut Pasal 1 Undang-Undang Nomor 30 Tahun 1999 tentang Arbitrase dan Alternatif Penyelesaian Sengketa Umum, yang dimaksud arbitrase adalah cara penyelesaian sengketa perdata di luar peradilan umum yang didasarkan pada perjanjian arbitrase yang dibuat secara tertulis oleh para pihak yang bersengketa. Di dalam undang-undang ini disebutkan pula Alternatif Penyelesaian Sengketa, yakni lembaga penyelesaian sengketa atau beda pendapat melalui prosedur yang disepakati para pihak, yakni penyelesaian di luar pengadilan dengan cara konsultasi, negosiasi, konsiliasi, atau penilaian ahli.

Lembaga hukum yang dapat digunakan untuk penyelesaian sengketa dalam transaksi perbankan melalui internet banking yakni melalui lembaga Alternetive Dispute Resolution (ADR). Di dalam sudut pandang yang luas, $A D R$ meliputi segala cara penyelesaian sengketa di luar pengadilan, dan secara garis besar $A D R$ dapat dikualifikasikan dalam negosiasi, good offices, mediasi, konsiliasi, arbitrase, dan kombinasi dari kelima media tersebut minitrial, summary jury trial, rent-a-judge, mediasi-arbitrase. ${ }^{16}$

Penyelesaian sengketa dalam transaksi perbankan melalui internet ini dapat saja dilakukan secara tradisional, misalnya melalui lembaga arbitrase. Untuk dapat dilakukan penyelesaian

${ }^{16}$ Nandang Sutrisno, Dasar-dasar Penyelesaian Sengketa Alternatif, Bandung: Alumni, 1999, hlm. 5. 
Asuan, Transaksi Perbankan Melalui Internet Banking, Halaman 317-335

sengketa melalui lembaga arbitrase, para pihak harus melihat apakah ada klausul arbitrase, dalam arti kata selain ada perjanjian pokok yang bersangkutan diikuti atau dilengkapi dengan persetujuan arbitrase. Dari berbagai sumber undang-undang, peraturan dan konvensi internasional dapat dijumpai dua bentuk klausul arbitrase, yakni Pactum de compromittendo dan Akta kompromis Pactum de compromittendo adalah para pihak yang mengikatkan kesepakatan akan menyelesaikan persengketaan yang mungkin timbul melalui forum arbitrase. Pada saat mereka mengikatkan dan menyetujui klausul arbitrase, sama sekali belum terjadi perselisihan. Sedangkan akta kompromis adalah sebuah perjanjian arbitrase yang dibuat setelah timbulnya perselisihan antara para pihak. ${ }^{17}$

Jika para pihak yang bersengketa dalam layanan internet banking telah melakukan kesepakatan untuk menyelesaikan sengketa melalui arbitrase, maka perlu ditunjuk arbiter yang dipilih oleh para pihak yang bersengketa atau yang ditunjuk oleh Pengadilan Negeri atau oleh Lembaga

17 Yahya Harahap, Beberapa Tinjauan Mengenai Sistem Peradilan dan Penyelesaian Sengketa, Bandung: PT. Citra Aditya Bakti, 1997, hlm. 100.
Arbitrase untuk memberikan putusan mengenai sengketa tersebut. Pasal 4 Ayat (1) Undang- Undang Nomor 30 Tahun 1999 tentang Arbitrase dan Alternatif Penyelesaian Sengketa Umum menyatakan bahwa "Dalam hal para pihak telah menyetujui bahwa sengketa di antara mereka akan diselesaikan melalui arbitrase dan para pihak telah memberikan wewenang, maka arbiter berwenang menentukan dalam putusannya mengenai hak dan kewajiban para pihak jika hal ini diatur dalam perjanjian mereka". Di dalam Pasal 3 disebutkan pula bahwa "Pengadilan Negeri tidak berwenang untuk mengadili sengketa para pihak yang telah terikat dalam perjanjian arbitrase". Akan tetapi, putusan arbiter hanya mempunyai kekuatan eksekutorial setelah memperoleh izin atau perintah untuk dieksekusi dari pengadilan.

Selain melalui arbitrase, sengketa yang terjadi antara para pihak dapat diselesaikan pula melalui Alternatif Penyelesaian Sengketa, yakni lembaga penyelesaian sengketa atau beda pendapat melalui prosedur yang disepakati para pihak, yakni penyelesaian di luar pengadilan dengan cara konsultasi, negosiasi, konsiliasi, atau 
Asuan, Transaksi Perbankan Melalui Internet Banking, Halaman 317-335

penilaian ahli.

Tahap-tahap penyelesaian sengketa melalui alternatif penyelesaian sengketa menurut Undang-Undang Nomor 30 Tahun 1999, yakni:

1. Pertemuan langsung para pihak

2. Penunjukan penasihat ahli atau mediator oleh para pihak

3. Penunjukan mediator oleh lembaga arbitrase atau lembaga penyelesaian sengketa.

4. Penyelesaian sengketa oleh lembaga arbitrase atau oleh arbitrase ad-hoc.

Setelah tahap-tahap tersebut, kemudian dilakukan pendaftaran ke Pengadilan Negeri yang berisi kesepakatan tertulis yang telah dicapai para pihak, selanjutnya dilakukan pelaksanaan kesepakatan yang telah dicapai. $^{18}$

Alternatif Penyelesaian Sengketa sebagai salah satu mekanisme penyelesaian sengketa nonlitigasi dengan mempertimbangkan segala bentuk efisiensinya dan untuk tujuan masa yang akan datang sekaligus menguntungkan bagi para pihak yang bersengketa. Alternatif Penyelesaian Sengketa ini diatur dalam Pasal 6 Undang-Undang Nomor 30

${ }^{18}$ Munir Fuady, Arbitrase Nasional, Bandung: PT. Citra Aditya Bakti, 2003, hlm. 130.
Tahun 1999 tentang Arbitrase dan Alternatif Penyelesaian Sengketa Umum. Sengketa atau beda pendapat perdata dapat diselesaikan oleh para pihak melalui Alternatif Penyelesaian Sengketa yang didasarkan pada itikad baik dengan mengesampingkan penyelesaian sengketa secara litigasi di Pengadilan Negeri, di mana sengketa diselesaikan dalam pertemuan langsung oleh para pihak dengan waktu yang ditentukan dan hasilnya dituangkan dalam suatu kesepakatan tertulis, yang bersifat final dan mengikat para pihak untuk dilaksanakan dengan itikad baik serta wajib didaftarkan di Pengadilan Negeri.

Berdasarkan upaya-upaya penyelesaian sengketa di atas, maka diharapkan sengketa yang terjadi antara para pihak dapat diselesaikan dengan memperoleh hasil putusan yang seadil-adilnya melalui upaya penyelesaian sengketa yang disepakati para pihak.

\section{PENUTUP}

Internet banking merupakan salah satu pelayanan jasa bank terhadap nasabah untuk memperoleh informasi, melakukan komunikasi dan transaksi perbankan melalui jaringan internet, 
Asuan, Transaksi Perbankan Melalui Internet Banking, Halaman 317-335

pelaksanaan apabila nasabah memiliki rekening bank, ATM dan User ID dan PIN untuk melakukan transaksi perbakan melalu internet banking yang berdasarkan pada pasal 1320 dan 1338 KUH Perdata. Undang-Undang Nomor 10 Tahun 1998 tentang Perbankan pada Pasal 5 tentang jenis bank yaitu bank umum dan bank perkreditan rakyat dan Pasal 40 tentang kerahasiaan bank termasuk masalah transaksi perbankan melalui internet banking serta perlindungan hukum yang diberikan oleh bank tentang kerahasiaan data nasabah.

Sengketa pada transaksi perbankan melalui internet banking (pihak bank dan debitur) dapat diselesaikan dengan mengacu pada perjanjian yang telah disepakati para pihak, penyelesaian sengketa dapat dilakukan melalui pengadilan (litigasi) ataupun di luar pengadilan (nonlitigasi) berdasarkan Undang-Undang Nomor 30 Tahun 1999 tentang Arbitrase dan Alternatif Penyelesaian Sengketa pada pasal 6 tentang sengketa umum dapat diselesaikan melalui arbitrase.

\section{DAFTAR PUSTAKA}

\section{A. Buku}

Budi Agus Riswandi, Aspek Hukum Internet Banking, Raja Grafindo
Persada, Jakarta, 2005.

Gunarto Suhardi, Usaha Perbankan dalam Perspektif Hukum. Kanisius, Yogyakarta, 2003.

Nandang Sutrisno. Dasar-dasar Penyelesaian Sengketa Alternatif, Alumni, Bandung, 1999.

Maryanto Supriyono, Buku Pintar Perbankan, Bandung: CV. Andi Ofsfet, 2010.

Mariam Darus Badrulzaman, Kontrak Dagang Elektronik Tinjauan Dari Aspek Hukum Perdata, Bandung: PT. Citra Aditya Bakti, 2001.

Munir Fuady, Arbitrase Nasional, Bandung: PT. Citra Aditya Bakti, 2003.

Kartini Muljadi Gunawan Widjaja, Seri Hukum Perikatan (Perikatan Pada Umumnya), Jakarta: Penerbit PT. Raja Grafindo Persada, 2003.

Rachmadi Usman, Aspek-aspek Hukum Perbankan di Indonesia, Jakarta: Gramedia, 2003.

Resa Raditio, Aspek Hukum Transaksi Elektronik; Perikatan, Pembuktian Dan PenyelesaianSengketa, Yogyakarta: Graha Ilmu, 2014.

Subekti, Hukum Perjanjian, Jakarta: PT Intermasa, Jakarta, 2002.

Sri Soemantri M, Bunga Rampai Hukum Tata Negara Indonesia, Bandung: 
Asuan, Transaksi Perbankan Melalui Internet Banking, Halaman 317-335

Penerbit Alumni, 2007.

Sutan Remi Sjahdeini, Hukum Siber

Sistem Pengamanan E-Commerce,

Bandung: PT Citra Aditya Bakti, 2001.

Yahya Harahap, Beberapa Tinjauan

Mengenai Sistem Peradilan dan Penyelesaian Sengketa.

Bandung: PT. Citra Aditya Bakti. 1997.

\section{B. Peraturan Perundang-undangan}

Undang-Undang Nomor 10 Tahun 1998 tentang Perbankan.

Undang-Undang Nomor 23 Tahun 1999 jo. Undang-Undang Nomor 3 Tahun 2004 tentang Bank Indonesia. Undang-Undang Nomor $\quad 30$ Tahun 1999 tentang Arbitrase dan Alternatif Penyelesaian Sengketa Umum.

Undang-Undang Nomor 8 Tahun 1999 tentang Perlindungan Konsumen

Peraturan Pemerintah Nomor 52 Tahun 2000 tentang Penyelenggaraan Telekomunikasi.

Surat Keputusan Direktur Bank Indonesia Nomor

27/164/KEP/DIR/1995 tentang

Penggunaan Teknologi Sistem Informasi oleh Bank.
Surat Keputusan Direktur Bank Indonesia Nomor

31/175/KEP/DIR/1998 tentang Penyempurnaan Teknologi Sistem Informasi Bank dalam Menghadapi Tahun 2000.

Surat Edaran Bank Indonesia Nomor 6/18/DPNP Tanggal 20 April 2004 tentang Penerapan Manajemen Risiko pada Aktivitas Pelayanan Jasa Bank Melalui Internet Banking.

\section{Internet}

http://www.bankmandiri.com, diakses

Tanggal 10-12 Juli 2019. 